\title{
Student Attitude to Internet Search Engines: Navigation and Optimization Problems
}

\section{Actitud de los estudiantes hacia los motores de búsqueda de Internet: problemas de navegación y optimización}

\author{
Aida V. Kiryakova* \\ Doctor of Education, Professor, Head of the Department of the General and Professional Pedagogics, \\ Orenburg State University, Orenburg, Russia. \\ ORCID ID: 0000-0001-6289-3797 \\ Liudmila G. Shabalina \\ $\mathrm{PhD}$ in Education, Teacher of Technical Disciplines Department, Buzuluk Humanitarian Institute of \\ Technology (Branch), Orenburg State University, Buzuluk, Russia. \\ ORCID ID: 0000-0003-1617-9546 \\ Olga S. Manakova \\ $\mathrm{PhD}$ in Education, Teacher of Technical Disciplines Department, Buzuluk Humanitarian Institute of \\ Technology (Branch), Orenburg State University, Buzuluk, Russia. \\ ORCID ID: 0000-0003-2731-5910
}

\section{Olga A. Mechkovskaya}

PhD in Geography, Associate Professor of the Department of Social and Cultural Activities and Tourism, Gzhel State University, Elektroizolyator, Russia. ORCID ID: 0000-0002-2227-6986.

Ekaterina L. Vodolazhskaya

Doctor of Economics, Professor of the Department of Economics, Organization and Production Management, Kazan National Research Technological University, Kazan, Russia. ORCID ID: 0000-0002-7669-4569

\section{Sofia Sh. Ostanina}

Doctor of Economics, Professor of the Department of Economics, Organization and Production Management, Kazan National Research Technological University, Kazan, Russia. ORCID ID: 0000-0001-5132-9656

\section{Larisa F. Komissarova}

$\mathrm{PhD}$ in Economics, Associate Professor of the Department of Economics, Organization and Production Management, Kazan National Research Technological University, Kazan, Russia. ORCID ID: 0000-0003-4116-7504

Received 09-08-20 Revised 10-10-20 Accepted 12-12-20 On line 03-12-21

* Correspondence

Email: aida@gmail.com

\section{Citation:}

\footnotetext{
Aida V. Kiryakova, Liudmila G. Shabalina, Olga S. Manakova Olga A. Mechkovskaya, Ekaterina L. Vodolazhskaya, Sofia Sh. Ostanina, Larisa F. Komissarova. (2021). Student Attitude to Internet Search Engines: Navigation and Optimization Problems. Propósitos y Representaciones, 9 (SPE3), e1128. Doi http://dx.doi.org/10.20511/pyr2021.v9nSPE3.1128
} 


\begin{abstract}
The article relevance. Currently, the world is rapidly undergoing the process of Informatization of all aspects of society, the development and introduction of new information technologies. This highlights the need for further reflection and research on the development of the Internet and its opening opportunities for people. The aim of the research is to study the peculiarities of the attitude of students to search and recommendation services on the Internet. Research methods: as a research method, we used a questionnaire survey as a method of collecting primary information, which allows us to identify various aspects related to the attitude of students to search and recommendation systems on the Internet. Research results: the article examines the specifics of Russian search and recommendation systems, students' attitude to these services, and their place in their lives. The novelty and originality of the research lies in the fact that for the first time the search and recommendation services of the Internet space were studied. It is shown that these services were initially developed in the sphere of culture and gradually began to spread to other spheres of people's life, which attracted e-Commerce figures. It is revealed that those students who discovered search and recommendation services a few years ago still use them to choose leisure activities. It is shown that students still identify some disadvantages of these systems: inaccurate recommendations, a large number of questions to determine preferences. There is some distrust to new Internet technologies among those who are used to relying on their intuition when choosing. It is determined that students often use search and recommendation services, since in most cases gadgets help them spend their free time, have fun: read a book, watch a movie, listen to music. It is revealed that the majority of students trust Internet services, although they are not always satisfied with the recommendations. It is shown that the level of student-user confidence in traditional advertising and marketing decreases simultaneously. It is determined that from the point of view of students, today not only printed versions of Newspapers, traditional radio, but even mass broadcast television are losing ground before the Internet as the most promising communication channel. Practical significance: the data Obtained in this work can be used in marketing research, economic Sciences, advertising psychology, as well as for further theoretical development of this issue.
\end{abstract}

Keywords: student youth, Internet, search and recommendation system, attitude.

\title{
Resumen
}

Relevancia del artículo. Actualmente, el mundo está experimentando rápidamente el proceso de informatización de todos los aspectos de la sociedad, el desarrollo y la introducción de nuevas tecnologías de la información. Esto destaca la necesidad de una mayor reflexión e investigación sobre el desarrollo de Internet y sus oportunidades de apertura para las personas. El objetivo de la investigación es estudiar las peculiaridades de la actitud de los estudiantes ante los servicios de búsqueda y recomendación en Internet. Métodos de investigación: como método de investigación, utilizamos una encuesta por cuestionario como método de recogida de información primaria, que nos permite identificar diversos aspectos relacionados con la actitud de los estudiantes hacia los sistemas de búsqueda y recomendación en Internet. Resultados de la investigación: el artículo examina los detalles de los sistemas de búsqueda y recomendación rusos, la actitud de los estudiantes hacia estos servicios y su lugar en sus vidas. La novedad y originalidad de la investigación radica en que por primera vez se estudiaron los servicios de búsqueda y recomendación del espacio de Internet. Se demuestra que estos servicios se desarrollaron inicialmente en el ámbito de la cultura y poco a poco se fueron extendiendo a otros ámbitos de la vida de las personas, lo que atrajo a figuras del eCommerce. Se revela que aquellos estudiantes que descubrieron hace unos años los servicios de búsqueda y recomendación aún los utilizan para elegir actividades de ocio. Se muestra que los estudiantes aún identifican algunas desventajas de estos sistemas: recomendaciones inexactas, una gran cantidad de preguntas para determinar preferencias. Existe cierta desconfianza hacia las nuevas tecnologías de Internet entre quienes están acostumbrados a confiar en su intuición a la hora de elegir. Se determina que los estudiantes suelen utilizar servicios de búsqueda y recomendación, ya que en la mayoría de los casos los gadgets les ayudan a pasar su tiempo libre, divertirse: leer un libro, ver una película, escuchar música. Se revela que la mayoría de estudiantes confían en los 
servicios de Internet, aunque no siempre quedan satisfechos con las recomendaciones. Se muestra que el nivel de confianza entre estudiantes y usuarios en la publicidad y el marketing tradicionales disminuye simultáneamente. Se determina que, desde el punto de vista de los estudiantes, hoy no solo las versiones impresas de Diarios, la radio tradicional, sino incluso la televisión masiva están perdiendo terreno ante Internet como el canal de comunicación más prometedor. Importancia práctica: los datos obtenidos en este trabajo pueden ser utilizados en investigación de mercados, ciencias económicas, psicología publicitaria, así como para un mayor desarrollo teórico de este tema.

Palabras clave: juventud estudiantil, Internet, sistema de búsqueda y recomendación, actitud.

\section{Introduction}

The sphere of Internet activity and the place of a person in it remains not fully studied, as every day there are opportunities, and with them the problems of implementing modern Internet technologies (Voiskunsky, 1997; Danilchuk, 2002; Serykh, 2006; Galiskan et al., 2019). The use of the Internet is becoming a necessary condition for successful social adaptation to the conditions of the information society and a new daily practice. The rapid development of new information and communication technologies and their increasing impact on all spheres of public life tell us that information and knowledge are becoming the main resource for further social development (Natolochnaya, Kryukova \& Buslaev, 2016; Akhmadieva et al., 2018; Razumovskaya et al., 2018). The formation of the information society is taking place, although with varying degrees of intensity and effectiveness, in almost all countries of the world, including Russia.

Recently, this process has been mainly determined by the development of the global computer network Internet, which is becoming a key technology and the main element of the information society infrastructure. All spheres of life move to the information space of global computer networks and there they transform and function in a new way, acquire their own specifics under the influence of technological and social aspects (Babaeva, Voiskunsky \& Smyslova, 2000; Rubanov, 2011; Rayanov, 2004; Danilova, 2002; Kubiatko, Usak \& Masalimova, 2016; Kutuev et al., 2017; Faleeva et al., 2017; Kvon et al., 2019; Ezhov et al., 2019). Nowadays, various aspects of human life are being informatized at a rapid pace. The introduction of Internet technologies leads to impressive results and modernization in the production and banking sectors, in business and public life, in science and education. The Internet environment is now the object of research in various Sciences, and it does not leave indifferent either sociology, psychology, or philosophy, such Sciences that, it would seem, should have nothing to do with technology. The powerful impetus for the development of science received in the information society should be associated today with the idea that this vector of development outside of culture and values is fraught with the threat of destroying nature, man, as well as science itself (Bell, 1999; McLuhan, 2004; Semenov, 2002). Thus, one of the consequences of total Informatization of society is its oversaturation with all kinds of information resources, an abundance of information on any aspect of human and social life. Any social practice, even the most private, is overgrown with a huge number of recommendations, instructions, tips for its application and optimization. There are thousands of feedback options available on the Internet for any particular question. In the information ocean, in order not to get lost in it, a reliable guide and assistant have long been needed.

\section{Literature Review}

Globalization has contributed to the development of the information society and has affected various areas of life: the development of e-Commerce; national organizations have appeared; financial markets have merged. A person entering a new information environment is faced with a global, inexhaustible information resource of humanity (Castels, 2004; Ananyev, 2001; Yershova, 2001; Gorev \& Masalimova, 2017; Rudenko et al., 2018; Vinogradova et al., 2018; Usak et al., 2020; Cherdymova et al., 2019; Bayanova et al., 2020; Putilina et al., 2019; Pushkarev et al., 2019). Moreover, in order for such a society to develop, society produces more and more information; it becomes qualitative and meets modern public needs. This phenomenon characterizes the development of modern society, as well as the fact that people need information, and there is a 
certain practice of searching for information on the Internet (Young, 2000; Makarov, 2016; Mikhaleva, 2017). In order to describe the essence of such phenomena, it is necessary to introduce definitions of some concepts and processes developing around this activity. Although the roots of recommendation services go back to works in the field of technological breakthroughs in information search systems, forecasting theories, and are also related to the science of managing and modeling consumer choice in the market, in the future we would like to reveal their social capabilities. It is the coincidence of the two sides of recommendation services, their technological and social touch that awakens the development of conflicting opportunities in them. You should also distinguish between the concepts of recommendation system and recommendation service. A recommendation system is a key technology for selecting products and services that are most likely to be purchased by a given user. By analyzing the history of viewing and purchasing products in all stores and the available information about the interests of each user, the recommendation system can significantly increase the conversion of advertising materials, changing the person's idea of the effectiveness of online advertising (Lebedev-Lyubimov, 2002; Belinskaya \& Zhichkina, 2004; Hermogenova, 1994).

Using new media technologies, a person must have a certain level of critical thinking and the ability to analyze and interpret incoming information, as well as develop skills of independent creative approach related to the search and processing of new material. This is one of the main requirements of modernity; everything around a person is permeated with information in order to socialize in modern society. From the above-mentioned, one can note that there are many approaches to describing the information society (Branovsky \& Shaposhnikova, 2001; Medvedeva, 1994; Mironova et al., 2017; Latysheva et al., 2018; Khanmurzina et al., 2020; Novak \& Hoffman, 2000; Bubnova et al., 2018; Stukalova et al., 2018). The Internet is the largest and most global space of its kind that unites people all over the world. It opens up new opportunities for communication, work, and learning, and affects all social aspects of life, which is why it is interesting for scientific discourse. Modern reality is changing faster and faster, sometimes one cannot catch up with it, it expands its new boundaries, and this process should be balanced.

The formation of a society based on information and communication technologies was marked by the emergence of new social ideas related to the concept of the information society (Tikhomirov, 1981; Chudova, 2002; Lipatov, 2004). The very concept of the information society has become working and forming social ideals and values that are widely discussed by a number of social Sciences and Humanities. Thus, in the information society, the Internet and its technologies are an integral attribute, the core around which the social formation is formed and develops. The Internet is developing very quickly, with new technologies emerging every day that researchers cannot keep up with in order to make a deep theoretical analysis (Kargapoltseva et al., 2019; Bayanova et al., 2019). That is why modern researchers in their works, not infrequently use ambiguous, definitions, which are not established in science and reflecting different points of view. Many moments can be missed because of the numerous processes taking place around new media. The structure of the information society is more complex than the structure of previous societies, since it is the fundamental link of this society. Computer communications are not an independent production unit, but are the product of a specific industry. Data search is the largest sector of the Internet economy. The most powerful online companies such as Yandex, Google developed around search engines. At the dawn of the Internet, all actions taken to find the right information were reduced to a single adviser - the search engine. It was an infrastructure where everyone could discover what he or she were interested in.

\section{The Study Objectives and Structure}

The research methodology was based on a questionnaire survey as a method of collecting primary information, which allows identifying various aspects related to the attitude of students to search and recommendation systems on the Internet.

To date, Runet has a huge number of search and recommendation services that are designed to solve the problem of choice in a variety of everyday situations. Initially, recommendation services 
began to develop in the cultural sphere. Since every day, there are more and more books, movies and music, and the average Internet user is not able to view and select high quality works of culture. Now such recommendations are relevant not only in the field of culture, but also in a regular grocery or hardware store.

To analyze and interpret the capabilities of these search and recommendation services, it is necessary to analyze the experience of using recommendations by ordinary student users. The study used a questionnaire method to find out from students whether they trust such Internet technologies. Questionnaire questions:

Do you use sites such as search services?

How long have you been using search and recommendation sites?

How often do you use search services?

Do you currently use these services?

If you stopped using search services, how long ago?

What are the reasons you ceased to use the data search and recommendation systems?

What search services do you use now?

What services do you use most often?

What do you most often search by using search and recommendation services (products or services)?

What kind of services and products do you most often search for on search and recommendation services?

Why do you seek help from recommendation services?

What are the advantages of search and recommendation services?

What are the disadvantages of search and recommendation services, if any?

How can search and recommendation services work more effectively?

What search services can you recommend to other people?

These questions were formulated in such a way as to find out the attitude of students to search and recommendation systems. These questions were organized into three units: determining the search and recommendation systems that students use, what students most often search by using these systems, and identifying the positive and negative characteristics of these systems.

\section{Features of Students' Attitude to Internet Search and Recommendation Services}

After studying the opinions of students about recommendation services, and what place they occupy in their lives, in General, we can note some reasons for the popularity of new gadgets. Students are open to applying various innovations and Internet technologies (100\%). Most of the respondents quickly and with interest learn new Internet tools in order to make it easier to work and have fun on the Internet in the future (86\%). The majority of students are happy to accept anything that allows them to take an active part in order to express themselves (64\%). Nevertheless, if the use of new Internet technologies takes longer than before, students are more likely to give up these gadgets $(34 \%)$. Since they are not willing to wait a single extra minute, this will be popular if it saves time. Thus, students spend more and more time on the Internet, both free and working, they are all immersed in this environment, which means that interest in such services will only grow. The majority of students indicated that using recommendation services not only helps them choose a product or service faster and not lose money (68\%), but also replaces every day, familiar communication practices in real life (54\%). The possibilities of search and recommendation services from the point of view of students are wide, they help to cope with the solution of a wide variety of issues, which determines their popularity and demand in society (68\%). In addition, these services make it easier to select and search for information; students much less time spend on this, and with great interest make changes in their lives, using new gadgets (86\%).

In General, students do not stop using recommendation services, they can change one site to another (64\%), use it sometimes less often, then more often (68\%), depending on their free time. However, those students who discovered recommendation services a year or two ago still use them to choose leisure activities (87\%). Despite the fact that the creators of recommendation services talk 
about the great popularity of recommendation services, students still highlight some shortcomings of these systems, such as inaccurate recommendations (34\%), a large number of questions to determine preferences $(80 \%)$. There was also some distrust of new Internet technologies among those who used to rely on their intuition when choosing (13\%). Recommendation services open up the possibility of forming a new channel to citizens, to study their interests and needs, and in the future, it is possible to influence society, which also calls recommendations into question. Students often use recommendation services, as in most cases gadgets help them spend their free time, have fun-read a book, watch a movie or listen to music (100\%). Now, almost the majority of students trust Internet services, although they are not always satisfied with the recommendations, because in the cultural sphere, it is easy to determine immediately whether they like the recommended book or not, just by reading the table of contents. However, with commercial sites, everything is much more complicated, and time will tell what attitude students will have to them.

\section{Discussions}

Today, the world is changing faster than people can comprehend it. Those who yesterday thought of themselves as an advanced Internet user, today the world wide web is baffled by its new capabilities resulting from the rapid progress of its technological equipment. The main principle of recommendation services is to give a more accurate recommendation and advise the information that will appeal to the person who chooses it. No one Respondent does not think about how the information collected about the user will be used in the future. But it is already clear even at first glance that despite how much information a person has not provided about himself, from this moment on he/she is in the circle of his/her interests, this phenomenon is described as a filter bubble, when based on his/her past interests, in the future he/she will be given information based on past interests, and therefore, the field of information narrows. There is a certain paradox, starting to study the essence of recommendation services, it seemed to us that this is a tool with which one can navigate the diversity of the information environment and solve the problem of finding the right information. It seemed that this new gadget is able to allocate only the necessary and interesting information. Now when recommendation services have begun to cope with this task, people began to worry: "what if there is something outside of our interests that we will like much more". This raises a new question: are recommendation services able to guess what we want? As practice shows, today they do not fully cope with this task.

The Internet is increasingly penetrating human life and bringing with it new tools for solving old problems. The modern world is characterized by new phenomena that have never existed before: blogs, social networks, and mass media, which manifest themselves in different ways in the Internet space. Every day people are faced with the question of choice. We choose products in the supermarket, movies to watch, artist and favorite songs, choose the way to work and mode of transport, places to relax, where we want to spend our free time, and what book to read on the way to work, on vacation.

\section{Conclusions}

Having studied the Russian experience in the development of recommendation services, one can be note that initially they were formed in the field of culture, but later became profitable for online Commerce.

The main principle of search and recommendation services is to give as accurate recommendation as possible and advise the information that a particular person will like. Such systems need to collect as much information as possible about a person's preferences, as well as side information that may affect their interests.

Students still highlight some disadvantages of these systems: inaccurate recommendations, a large number of questions to determine preferences. In most cases, gadgets help them spend their free time, have fun: read a book, watch a movie, and listen to music. Students who discovered search and recommendation services a few years ago still use them to choose leisure activities. They express the opinion that the problem of the modern Internet space is that it is very difficult to find necessary 
and useful information in such a variety of constantly increasing amounts of information. A person is not able to learn everything that the manufacturer offers. Previously, in most cases, recommendations from friends and acquaintances helped to make this choice. Now, when individual competence is no longer enough to make a choice, people are increasingly turning to the Internet with their questions, where sites such as recommendation services have begun to develop, which help to answer the question of what to choose from the entire variety of information on the World Wide Web.

The fundamental innovation of search engines in the context of their significance for the media industry is that in conditions when the information consumer gets independent access to media content (without relying on someone else's ideas about significance), and selects content from an unlimited number of sources, the only way to navigate in this palette of content is a search robot.

Thus, for most people today, technology is beginning to play an increasing role in navigating and helping them make choices from a large number of alternatives. One of the most striking characteristics and features of the Internet is social personalization, i.e. all information is becoming more focused on the tastes and preferences of the consumer.

\section{References}

Akhmadieva, R.S., Yakusheva, I.P., Fabrikov, M.S., Kryukova, N.I., Perkova, E.P., Ibraeva, G.R., Platonova, E.V., \& Gallyamova, O.N. (2018). Mastering of Student Valeological SocioCultural Etalons in Pedagogically Organized Environment of College and University. Modern Journal of Language Teaching Methods, 8(9), 175-184.

Ananyev, B.G. (2001). On the problems of modern human studies. Saint Petersburg: Piter.

Babaeva, Yu.D., Voiskunsky, A.E. \& Smyslova, O.V. (2000). Internet: impact on the individual. Humanities research on the Internet. Moscow: Mozhaisk-Terra.

Bayanova, A.R., Sivova, I.V., Kamasheva, Y.L., Popova, O.V., Semyanov, E.V., Shagieva R.V. \& Yusupov, I.M. (2020). Student online services consumption: Routine practices or mistrust to digital service? Contemporary Educational Technology, № 11(1),47-54.

Bayanova, A.R., Vodenko, K.V., Sizova, Zh.M., Chistyakov, A.A., Prokopiev, A.I., \& Vasbieva, D.G. (2019). A philosophical view of organizational culture in contemporary universities. European Journal of Science and Theology, 15(3), 121-131.

Belinskaya, E. \& Zhichkina, A. (2004). Modern studies of virtual communication: problems, hypotheses, results. Moscow: UNITY-DANA.

Bell, D. (1999). The Coming post-industrial society. Experience of social forecasting. Moscow: Akademia.

Branovsky, Yu.S. \& Shaposhnikova, T.L. (2001). Information and innovative technologies in professional education. Krasnodar: publishing house of Kuban state tekhnol. University.

Bubnova, I.S., Khvatova, M.A., Chernik, V.E., Popova, O.V., Prokopyev, A.I., Naumov, P.Y., \& Babarykin, O.V. (2018). Research of Professional Activity Features of Ecologist at Carrying Out Public Ecological Examination. Ekoloji, 106, 999-1006.

Caliskan, S., Guney, Z., Sakhieva, R.G., Vasbieva, D.G., \& Zaitseva, N.A. (2019). Teachers' Views on the Availability of Web 2.0 Tools in Education. International journal of emerging technologies in learning, 14(22), 70-81.

Castels, M. (2004). Galaxy Internet: Reflections on the Internet, business and society. Yekaterinburg: U-Factoriya (with the participation of the publishing house of the Humanitarian University).

Cherdymova, E.I., Prokopyev, A.I., Karpenkova, T.V., Pravkin, S.A., Ponomareva, N.S., Kanyaeva, O.M., Ryazapova, L.Z., \& Anufriev, A.F. (2019). EcoArt Therapy as a Factor of Students' Environmental Consciousness Development. Ekoloji, 107, 687-693, Article No: e107085.

Cherdymova, E.I., Vorobyeva, K.I., Romashkova, O.V., Mashkin, N.A., Grigoriev, S.M., Romanchenko, L.N., Karpenko, M.A. \& Bayanova, A.R. (2018). Photo Exhibition Influence on Student Environmental Consciousness Formation. Ekoloji, 27(106), 1271-1278.

Chudova, N.V. (2002). Features of the image of the self of the Internet inhabitant. Psychological journal, 23(1), 114-118. 
Danilchuk, E.V. (2002). Information technologies in education. Volgograd: Peremena.

Danilova, Z.K. (2002). Course in information technology. Additional education, 3, 58-60.

Ezhov, K.S., Cherdymova, E.I., Prokopyev, A.I., Fabrikov, M.S., Dorokhov, N.I., Serebrennikova, Y.V., Belousov, A.L. \& Efimova, O.S. (2019). Conflict features depending on stay duration at workplace. Dilemas contemporáneos: Educación, Política y Valores, 4(38).

Faleeva, L.V., Bratukhina, E.V., Ezhov, S.G., Gorbunova, L.N., Lopanova, A.P., Viaznikova, L.F., \& Kryukova, N.I. (2017). Student's Social Experience Forming in University Vocational Training. Eurasian Journal of Analytical Chemistry, 12(7B), 1127-1135.

Gorev, P.M. \& Masalimova, A.R. (2017). Development of Meta-Subject Competencies of the 7-9 Grades Basic School Students through the Implementation of Interdisciplinary Mathematical Courses. Eurasia Journal of Mathematics Science and Technology Education, 13(7), 3919-3933.

Hermogenova, L.Yu. (1994). Effective advertising in Russia. Practice and recommendations. Moscow: Delo.

Kargapoltseva, N.A., Rakhimova, O.N., Shabalina, L.G., Guryanova, T.Y., Mashkin, N.A., Mirzalimov, R.M. \& Popova, N.F. (2019). Student Identity and Various Procedures of its Development. International Journal of Applied Exercise Physiology, 2, 519-526.

Khanmurzina, R.R., Cherdymova, E.I., Guryanova, T.Yu., Toriia, R.A., Sukhodolova, E.M. \& Tararina, L.I. (2020). Computer games influence on everyday social practices of studentsgamers. Contemporary Educational Technology, 11(1), 11-19.

Kubiatko, M., Usak, M., \& Masalimova, A.R. (2016). Czech Lower Secondary School Pupils' Knowledge about Developing Countries. Revista de Cercetare si Interventie Sociala, 55, 215-230.

Kutuev, R.A., Mashkin, N.A., Yevgrafova, O.G., Morozov, A.V., Zakharova, A.N. \& Parkhaev, V.T. (2017). Methodological Guidance of Educational Monitoring Effectiveness. Modern Journal of Language Teaching Methods, 7(3), 405-41.

Kvon, G.M., Vaks, V.B., Kalimullin, A.M., Bayanova, A.R., Shaidullina, A.R., Dolzhikova, A.V. \& Lapidus, N.I. (2019). Developing the Informational and Digital Environment of a University: Problem Analysis and Assessment. Eurasia Journal of Mathematics, Science and Technology Education, 15(10), em1767. URL: https://kpfu.ru/staff_files/F1126799205/Developing_the.pdf

Latysheva, V.V., Bulgakova, V.O., Sidorenko, G.G., Korenko, J.M., Khairullina, E.R., Shaidullina, A.R., Bayanova, A.R. (2018). Subjective Environmental Attitude Features to Nature of Specially Protected Areas Employees. Ekoloji, 27(106), 1801-1809.

Lebedev-Lyubimov, A. (2002). Psychology of advertising. St. Petersburg: Piter.

Lipatov, V.V. (2004). Formation of information culture in the process of creating Web sites. Additional education, 1, 58-60.

Makarov, Yu.N. (2016). Social consequences of the Genesis of the information society. Scientific and theoretical journal "Economic and humanitarian research of regions", 2, 16-27.

McLuhan, M. (2004). Means is the content itself. Information society. Moscow: ACT. 341-348.

Medvedeva, E.A. (1994). Fundamentals of information culture. Socis, 11, 59-65.

Mikhaleva, O.V. (2017). Information technologies in the formation of communicative competence. Proceedings of the Institute of education management of the Russian Academy of education, 4(64), 110-113.

Mironova, M.D., Zaitseva, N.A., Larionova, A.A., Akhpolova, V.B., Glagoleva, L.E., Belozerova, J.M. (2017). Features of Innovative Personnel Management of Service Companies in the Period of Implementation of Organizational Changes. Eurasian journal of analytical chemistry. 12(5B), 793-802.

Natolochnaya, O.V., Kryukova, N.I., \& Buslaev, S.I. (2016). The development of the public education system in the Caucasus in the pre-revolutionary period (1905-1917 years). Bylye Gody, 39(1), 222-228.

Novak, T. \& Hoffman, D. (2000). New metrics for new media: towards developing standards for measuring Web audiences. Humanities research on the Internet. Moscow: "MozhaiskTerra".

Pushkarev, V.V., Cherdymova, E.I., Prokopyev, A.I., Kochurov, M.G., Shamanin, N.V., Ezhov, S.G., Kamenskaya, S.V. \& Kargina, N.V. (2019). Motivation and needs in the area of the 
spouses with different experiences of cohabitation. Dilemas contemporáneos: Educación, Política y Valores, 4(Special Edition), 41-52.

Putilina, E.S., Meleshko, G.S., Cherdymova, E.I., Kurbanov, R.A., Belyalova, A.M., Shatskaya, I.I., Kobzeva, E.I. \& Zhuravleva, M.V. (2019). Ecological relationships in real and virtual environments: contact points. EurAsian Journal of BioSciences, 13(2), 1475-1480

Rayanov, M.R. (2004). Internet culture in the context of pedagogical activity. Information and educational technologies: Collection of scientific articles. Samara: SamSU publishing house.

Razumovskaya, M.I., Larionova, A.A., Zaitseva, N.A., Orekhov, V.D., Trufanova, S.N., Korzhanova, A.A., \& Takhumova, O., (2018). Modeling the network integration space for educational programs. Modern journal of language teaching methods, 8(5), 56-67.

Rubanov, A.V. (2011). Information society: methodology and research experience. "Post-Soviet space in the world order of the XXI century: priorities, features, future". Minsk: Mediafact.

Rudenko, L.G., Larionova, A.A., Zaitseva, N.A., Kostryukova, O.N., Bykasova, E.V., Garifullina, R.Z., Safin, F.M. (2018). Conceptual model of training personnel for small business services in the digital economy. Modern journal of language teaching methods, 8(5), 283-296.

Semenov, I. (2002). Internet and Russian society. Moscow: Gepdalf.

Serykh, L.A. (2006). Internet literacy as an element of the student's information culture. Proceedings of Samara scientific center of the Russian Academy of Sciences, special issue "Actual problems of humanitarian research", 4, 237-345.

Stukalova, O.V., Akhmadieva, R.S., Khasyanov, O.R., Faleeva, L.V., Ashrafullina, G.S., Fortova, L.K., Kochneva, L.V., \& Kryukova, N.I. (2018). Modern Trends in Educational Institutions Education Quality Assessment. Modern Journal of Language Teaching Methods, 8(9), 197208.

Tikhomirov, O.K. (1981). Information and psychological theory of thinking. Moscow, MSU publishing House.

Usak, M., Masalimova, A.R., Cherdymova, E.I., \& Shaidullina, A.R. (2020). New Playmaker in Science Education: COVID-19. Journal of Baltic Science Education, 19(2), 180-185.

Vinogradova, G.A., Akhmadieva, R.Sh., Konovalova, V.M., Spirina, E.V., Kalugina, O.A., Erdyneeva, K.G., Popova, N.N., \& Mashkin, N.A. (2018). Releasers as Factor of Student Ecological Focus Formation. Ekoloji, 27(106), 1409-1415.

Voiskunsky, A.E. (1997). Group gaming activity on the Internet. Psychological journal, 20, 126132.

Yershova, T.V. (2001). Information society and development of Russia. Information society, 2, $42-$ 44.

Young, K. (2000). Diagnosis of Internet addiction. The World Of The Internet, 2, 24-29. 